\title{
Needs Assessment of Grade 8 Instructional Materials in Teaching Filipino: A Phenomenology
}

\author{
Camille N. Dumpang ${ }^{1}$, Mary Anne C. Sedanza ${ }^{2}$, Las Johansen B. Caluza ${ }^{3}$ \\ ${ }^{1}$ College of Education, Leyte Normal University, Tacloban City,6500, Philippines \\ (camille.dumpang@lnu.edu.ph) \\ ${ }^{2}$ College of Education, Leyte Normal University, Tacloban City,6500, Philippines \\ (maryanne.sedanza@lnu.edu.ph) \\ ${ }^{3}$ College of Arts and Sciences, Leyte Normal University, Tacloban City,6500, Philippines \\ (lasjohansencaluza@1nu.edu.ph)
}

\begin{abstract}
Instructional materials are the tools used to educate learners and help the teaching-learning process be more effective and meaningful. However, teachers face problems regarding sources of information or materials to be used in instruction especially those teaching in public schools. Using a qualitative single-case study design, this study aims to determine the available instructional materials used by the Filipino Subject Teacher in a National High School which was identified by the City Division to be one of the low performing schools in the city based on the National Achievement Test 2016. This study will use purposive sampling and the use of semi-structured interviews as it links to Instructional Design Theory that worries how the student is going to learn and not more than what the student is going to learn. Results of this study could provide necessary assistance or school intervention for teachers teaching Filipino subject.
\end{abstract}

Keywords: Education, Needs Assessment, Instructional Materials, Qualitative Single Case Study, Leyte, Philippines

\section{Introduction}

Instructional materials are the resources that teachers use to deliver instruction. It can help student learning and improve student success. Ideally, the instructional materials will be personalized to the context in which they're being used, to the students in whose class they are being used, and to the teacher. instructional materials have one thing in common, that is the ability to support student learning (The Importance of Learning Materials in Teaching, 2016).

Instructional materials are determined as resources that sort and help instruction, such as books, activities, and supplementary resources (Remillard \& Heck, 2014). They strengthen the teaching/learning process by presenting information needed to obtain knowledge and skills (Campbell, 1999). Instructional materials are the tools used to educate learners and help the teaching-learning process be more effective and meaningful. However, teachers face problems regarding sources of information or materials to be used in instruction especially those teaching in public schools.

The unavailability of learning materials is just one of the problems still hounding the country's new basic education program, $\mathrm{K}$ to 12 , in its implementation (Legaspi, 2014). Using instructional materials in teaching and learning nowadays is not new. What is new is that the technological equipment that we adapted and have been introduced to us throughout the years. Because of these technologies used in teaching, we must therefore know the effective use and proper application of these materials. It has been proven that the use of these technological types of equipment as instructional aides are beneficial to learners and educators. Teachers must keep in mind the purpose for which instructional materials are used and the basis for selecting the materials that are most likely used to help learners achieve learning. According to Ogaga et.al, (2016) Instructional materials and their usage have a profound influence on student academic performance and achievement. However, many teachers find it difficult to use these types of instructional aids because of their availability and lack of training on their application for effective use.

This study aims to determine the available instructional materials used by the Filipino Subject Teacher in Northern Tacloban City National High School which was identified by the City Division to be one of the low-performing schools in the city based on the National Achievement Test 2016. Results of this study could provide necessary assistance or school intervention for teachers teaching Filipino subject.

\section{Review of Related Literature}

Instructional materials have been defined by various authors. Obanya (1989) sees them as a informative material thing

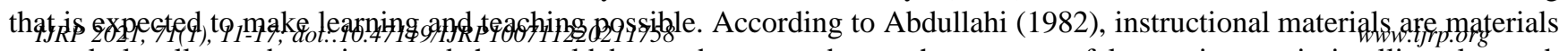
or tools locally made or imported that could be made tremendous enhancement of lesson impact is intelligently used. Ikerionwu (Isola, 2010) as cited in Agina-obu (2005) mention them as objects or devices, which aid the teacher to make a 
lesson much understandable to the learner. Instructional materials are also defined as concrete objects which provide sound, visual, or both to the sense organs during lessons.

Onyeachu (2010) explained instructional materials as method of making the teaching and learning process easy, more meaningful, and clearer. Instructional materials are in numerous classes, such as audio or aural, visual or audiovisual. Thus, audio instructional materials attribute to those devices that make use of the sense of hearing only, like radio and audiotape recording. Visual instructional materials are those tools that engage to the sense of both hearings and seeing such as television, motion picture, and the computer (Ambrosio Jr., 2016).

Teaching materials are the means that a teacher uses to provide instruction. Each teacher requires a range of tools to draw upon to assist and support student learning. These materials play a large responsibility in making learning accessible to a student and can encourage them to engage with knowledge in different ways (Teaching Materials, 2017). One essential dimension in teacher education that is getting a lot of attention is connected to the use of instructional materials. Instructional materials are those materials used by a teacher to abridge their teaching. They include both visual and audiovisual aids and could either be concrete or non-concrete (Tuimur, 2015).

Teachers need to make ensure that the materials that they take align with the need and strengths of their students. Other things to consider when selecting materials are the interests and choices of the students, length of book, background knowledge, and book series (Cox, n.d.).

Valued outcomes and learner need to determine what instructional materials and learning opportunities are used; the teacher's job is to provide the conditions for student access. Teachers and students use a broad quality of instructional materials to attain valued learning results. Instructional materials mainly specify to include a variety of media, manipulatives, and supplies. Instructional materials are well-suited with integration across the curriculum together with single discipline study. Instructional materials are modernized swiftly in response to new information and understandings. Student end product and developmental suitability determine when and by whom instructional materials will be utilized. Instructional materials convey the needs of the total child: cognitive, social, emotional, physical, and aesthetic. Instructional materials link subject area content to real-life applications. Teachers choose from a broad range of quality materials.

Students clearly understand that instructional materials are a means to acquiring the knowledge and competencies that are the valued outcomes of a course of study. Students make choices about instructional materials as part of the learning process. Students use instructional materials when working alone and in groups, in the classroom, and experiential learning situations. Students connect with instructional materials to hold all modalities in the learning process. Technology is integral to students learning experiences. Technology enhances students' higher-order, creative thinking and problem-solving. The demand of the students at different performance levels are connected by using different instructional materials that let students to draw on all of their learning dimensions. Reference and resource materials are pass on throughout the school so that they can be promptly used by students and teachers. Consumable instructional materials are usually non-print supplies that encourage active, hands-on learning. Purchase procedures are simplified to reduce the mistake between ordering and receiving instructional materials and to increase teachers' instructional flexibility (Handbook for Instructional Materials, n.d.).

Gravoso (2008) stressed out that efforts to improve students' learning outcomes have suggested the need to embed the use of educational technology in a learner-centered learning environment where students construct their meanings. To facilitate student-centered learning, many authors suggest the use of media and technology (Wang \& Woo, 2007). However, in this type of instruction, technologies should move their role from being courier of information to a way for engaging students in analyzing. More precisely, technologies should be used to present problems to students, give related cases and information resources, a social medium to help learning through cooperation and interaction, and intellectual partners to aid learning by reflecting (Jonassen, Peck, \& Wilson, 1999). Hence, technologies will not anymore become "full" systems (Zucchermaglio, 1994) that do nothing but send information to the students, tools that can guide them to experience the knowledge construction process (Edelson, Pea, \& Gomez, 1996).

A study carried out by Nwike and Onyejegbu (2013) revealed that those students taught with instructional materials performed better than those taught without instructional materials. This discovery is in line with the work of Olagunju (2000) who ascertained that there was an exceptional difference in the achievement scores of students taught with different instructional materials and those not reveal to the use of instructional materials. There is therefore a consensus that instructional materials enhance teaching and learning and leads to better students' achievement. This shows that students learn and perform better when they are taught with instructional materials because the use of instructional materials allows the students to see, feel and touch the materials during teaching. Okendu (2012) asserted that disciplined instructional management has a significant connection on students' academic performance. He also affirmed that an ampplërrapsply of instructional resources has a significant effect on the students' academic performance. As asserted by Onyeachu (2008), no matter how good a curriculum plan is, if there are badly planned and outlined instructional materials and other inputs, the point may not be achieved. 
The instructional teaching materials make the teaching and learning easier because it captures the attention of the learners, facilitates the understanding of an abstract concept, saves time by limiting the use of wordy explanation, it provides the learner with the opportunity to manipulate an object in the environment (Ambrosio Jr., 2016).

Hence, it is important to note what are the available instructional materials the teacher has in class at present, what the teacher can say about these materials in terms of their usage and effectiveness, and what materials does the teacher think are necessary for his learners since the existing literature enumerates on the importance of instructional materials in the teaching-learning process. This urges the researchers to conduct this study to assess the needs of Grade 8 instructional materials in teaching Filipino especially that it was identified by the City Division to be one of the low-performing schools in the city based on the National Achievement Test 2016. Results shall provide an empirical basis for necessary assistance or school intervention for teachers teaching the Filipino subject.

\section{Theoretical Framework}

This study is anchored on the Instructional Design Theory and is believed to have some bearing on the problem ventured to. This theory relies on the thought on how the student is going to learn and not om what the student is going to learn. It focuses on various methods designed to ensure learning in the classroom will take place in a safe, constructive, and effective way. It attempts to address how to get to the result.

This theory hints that a student will learn when the designed lesson relates to their needs and that students can easily use the material provided for the lesson. The outcome of the lesson helps determine if the Instructional Design was effective or not (Dick, 2010).

This theory reflects the teacher's initiative to provide ways on how the students will learn despite not having textbooks or supplementary materials in their school.

\section{Methodology}

\subsection{Research Design}

Husserlian descriptive phenomenology research design was utilized by the researchers to elicit the descriptions of the lived experiences of the participants about the available instructional materials used by the Grade 8 Filipino Subject Teacher in a public national high school in Tacloban City which was identified by the City Division to be one of the low performing schools based on the National Achievement Test 2016. Descriptive phenomenology design is widely used by social science research as a method of describing and exploring the lived experiences of individuals who had experienced a particular phenomenon (Christensen, Welch, \& Barr, 2017). In Husserl's conception of phenomenology, any experienced phenomenon could be the object of study thereby pushing analysis beyond mere sensory perception (i. e. what I see, hear, touch) to experiences of thought, memory, imagination, or emotion (Neubauer, Witkop, Varpio, 2019).

4.2 Research Setting and Sampling

This study was conducted in a public national high school in Tacloban City which was identified by the City Division to be one of the low performing schools based on the National Achievement Test 2016. Purposive sample was utilized using selection criteria set by the researchers. Anent to this, the participant should be a teacher handling Filipino subjects. There was only one Filipino Subject Teacher in the Grade 8 level that is why we only focused on him as our participant for this study. Purposive sampling and semi-structured interviews were used during the data gathering of the researchers. The researchers based this judgment when choosing participants of the study (Patton, 2002). This research involves identifying and selecting an individual that is most knowledgeable in the subject and has direct contact with students. (Creswell \& Plano Clark, 2006).

\subsection{Data Collection and Analysis}

Interview procedures were used to enable researchers to develop first person descriptions of diverse human experiences (Polkinghorne, 1989; Kvale, 1996; Thomas and Pollio, 2002). Structured interview guide questions were prepared by the researchers to elicit necessary information in assessing how the teacher is in terms of provision for instructional materials. Upon meeting the participant, we explained to him our intention regarding the instructional materials he has as a Filipino subject teacher. Answers were recorded and transcribed with his permission.

The qualitative data gathered from the interviews was transcribed and encoded using word document in identifying the significant statements and was copied to MS Excel for generating categories and emerging themes. Specifically, this study adopted the process of Colaizzi's descriptive phenomenological method of data analysis. Colaizzi's descriptive process of data analysis has seven steps such as 1) familiarization of data, 2) identifying significant statements, 3) formulation meanings, 4) clustering of themes, 5) developing an exhaustive discussion, 6) producing the fundamental structures, and 7) Seeking verification of the fundamental structure (Morrow, R., Rodriguez, A., \& King, ,NWw. 201015).

\subsection{Ethical Considerations}

The researchers sought the City Division Officials and the School Principal's permission. Upon meeting the 
participant, our intention for an interview was carefully narrated and explained. Recording the interview was also consented to by the participant.

\subsection{Researcher's Reflexivity}

The researchers of this study are state university's Faculty teaching in the laboratory school and in college. Multidisciplinary approach was utilized in this study to see the multiple views or facets of the phenomenon in order to arrive a common view about the topic under investigation. The researchers used code-switching (Waray/Filipino/English) in ensuring that the participant understood the questions and may answer in his preferred language.

In addition, the first author is presently a faculty in the laboratory school of the same university whose current contributions to research are guided with phenomenology and case study designs. She is an instructor whose field expertise is in Filipino, teaching, and learning.

The second author is also an instructor in the laboratory school of the same university wherein her research interests in qualitative research are phenomenology and case study. Her research work is in line with these models while her field expertise is in language, teaching, and learning.

The third author is a faculty in the tertiary level of the same university wherein his field of interest in qualitative research are transcendental and descriptive phenomenology, single case study, multiple case study, embedded single case study, embedded multiple case study, and content analysis using conceptual and relation analysis. His publications in qualitative research are within these designs. Moreover, his other interest is mixed methods such as parallel design, concurrent design, sequential exploratory design, and sequential explanatory design. While his field expertise is in information technology and computer science specifically the unsupervised machine learning, sentiment analysis, text analysis, simulations and modeling, and application of machine learnings. He is an Associate Professor 5 of the same university. Therefore, the third researcher can provide significant contributions in data processing, analysis, interpretation, and development of technology-based and contextualized instructional materials needed by the participants. It is noted that his past experiences could affect the analysis and interpretation of the data, however, constant reflection by reminding the purpose of the study and interpreting through the lens of the participants is advised.

\section{Results and Discussion}

A descriptive analysis of the data gathered revealed themes based on the needs assessment of Grade 8 instructional materials in teaching Filipino. Each theme was labeled based on the language used by the participant in describing specific meanings.

\subsection{Available Classroom Instructional Materials}

\section{Theme 1: Teacher's initiative}

It is noted that the participant makes use of what he has. He provides in his ways what lacks. He comments on the content found in the book from DepEd and find it difficult to use since there are no suggested activities. He also looks for other references and finds them on the internet which is easy for students to understand and allows his students to photocopy his reference. It is noticed then that he has very limited resources. This clearly shows that the teacher commits to use his initiative of having a personal and responsible decision instead. Such findings support the study of Tety (2016) that many schools in the study area do not use appropriate instructional materials. This is understood that, although the teachers have the understanding about the significance of instructional materials, they are not prepared to reinforce them. This may have many reasons. One could guess that teachers do not care whether the students perform or not, and this from the management point of view, may emanate from low morale and motivation towards their teaching. Another explanation may be the lack of supervision from the school heads. Commonly, the heads are supposed to be supervisors to ensure that directive are going on and students are equipped with quality education associated with quality instructional resources. Lack of management may be the cause for the situation found by this study. It also clearly reflects in the study of Dick (2010) that the teacher's initiative provides ways on how the students will learn despite not having textbooks or supplementary materials in their school.

Significant Statement 1. "Libro, akon libro, akon mismo kwarta. Pero mga learning material nagprovide an DepEd. Sometimes pagud, it libro damo it sayop, diri nagtutugma hit curriculum guide ha learning materials. An libro ha grade 8 , sarang, magulo hiya hin lesson. Waray hiya exercises"

(Books which I bought from my pocket. DepEd provided us some learning materials but sometimes these learning materials are not in line with the curriculum guide. The lessons in the book of Grade 8 are messy and are not properly arranged. There are no exercises.") (P3)

Significant Statement 2. "Namimiling ako hin references na madali makaintindi it mga bata. Sugad ha internet". (I look for some references that are easy for my students to understand, like from the internet.") (P3) ${ }^{\text {www.ijrp.org }}$

Significant Statement 3. "May ada ako mga references pero an mga bata waray. Yana nag-aadvance kami, ginassign ko hira hin reporting ginpaphotocopy ko hira para makabasa hira. Tapos naghihimo hira hin visual aids, para 
mabasa gihap an ira mga classmates. Amo tam ginbubuhat yana."

(I have my references, but the students don't have them. That is why I let them photocopy the reference I have for them to have advance reading and I assigned them to have reportings so that their classmates can also read. As of now, that is what we are doing”.) (P3)

\section{Theme 2: Frequently utilized visual aids}

The participant uses what he can readily use such as pictures, manila paper, and whiteboard. Based on the statement of the participant in this study, he stated the necessary materials they need to have and to be more effective in the teaching-learning process. He also shows his enthusiasm to have his materials in his lessons. As mentioned in the study of Lashley (2019), forty-five percent of teachers revealed that they use whatever instructional materials are available, whatever they can make or acquire within the school or at home. This implies that the participant worries how the student is going to learn and not so much on what the student is going to learn which is normally common among teachers.

Significant Statement 1. "Dire na gud ako nagamit chart, usually pictures tapos manila paper, cartolina strips tas white board so far nahihimo ko man ito hiya. Nakakahimo ako visual aids kay waray man ako klase hit aga pero amo manggud liwat iton, agi it kadalian pirme nala manila paper nahihimo kay waray naman time gud it akon paghimo hin mga colorful materials. So far okay man."

(I don't usually use charts, but pictures and manila paper, cartolina and whiteboard are what I am using. I can make visual aids sometimes because I don't have class in the morning but because of my limited time it is hard for me to use very colorful visual aids and I just often used manila papers. At least, it is still useful.") (P5)

\subsection{Views on the Usage and Effectiveness of Classroom Instructional Materials}

\section{Theme 3: Importance of Audio-visual equipment}

The findings show that the participant agrees then that audiovisual materials are effective as the students become more focused and are interactive considering that each class has a high number of students. Wondimtegegn (2020) said that the insufficient availability of instructional materials and finite methodology affects effective dissemination of the lesson/ needed information. To achieve desired goals, all the stakeholders concerned must ensure availability of required resources, employment of a variety of methodologies to arouse interest in the learners and also train all personnel involved to disseminate information. It was known that audiovisual aids have positive impact on students, teachers, and schools. The failure to recognize the importance of audiovisual aids will always lead pupils into misunderstanding the text/message.

Significant Statement 1. "Yana, libro gudman, kulang pa kay nagshasharing hira hin libro. Kay damo ini nga kabataan, 50 plus nga mga estudyante, it ira libro la 30 danay 25 la. Audio-visual materials kay effective gudman hiya. Focus hira kun may ada hira nakikit-an. Nagiging interactive it mga bata basi hit ira nakikit-an. Kailangan talaga ig-guide hira kay kon papabasa mo la diri hira nakakaintindi kay it iba nga mga bata liwat nganhi kay mga hubya manbasa, anyway may ada man talaga iton na mga bata na nag lay-low la."

(As of now, we have limited books. We have 50 plus students and we only have 30 or 25 available books that is why they are just sharing. Audio-visual materials are effective because students become focused on what they see and they become more interactive. We just need to guide them because if you just let them read, they won't easily understand and some students are not fond of reading”.) (P4)

\subsection{Instructional Materials Necessary for Learners}

\section{Theme 4: Audio-Visual integration in teaching}

The participant emphasized the need for Audio-visual equipment such as the LCD projector or other technologyintegrated materials. As mentioned in the study, Audio-visual Aids are those devices which are used in classrooms to encourage teaching-learning process and make it easier and interesting. It helps to sustain their attention for effective learning. It is the best aid for making instruction successful and the best dissemination of learning. It provides the learners with realistic experience, which captures their attention and helps in their understanding. It is the instructional device that can be heard and seen. Audio-Visual Aids are the procedure of communicating with people. The edge of audio-visual aids are to indicate the day's topics. Moreover, it was evident in the study of Bugler, et.al. (2017) that curriculum providers may need to communicate more clearly about how teachers were involved in the development and refinement of instructional materials, and about how the materials meet teachers' quality concerns. This indicates that teachers should be provided with the necessary materials to ensure that teaching is supported by resources that can process meaningful learning experience.

www.ijrp.org

Significant Statement 1. "Like audio-visual amo iton it amon kailangan. Mga libro, kulang gihap hin libro nganhi. Labi na kanan libro hin Noli Me ngan El Filibusterismo, pati Florante at Laura waray gihapon. Maupay nala mayda 
ako na-download na kanan El Filibusterismo, amo nala akon gamit pagpakita ha ira. Animated hiya."

(Audio-visual materials are also what we need. We also have limited books here and we don't have books in Noli Me Tangere and El Filibusterismo, also with Florante at Laura. The good thing is that I was able to download an animated video about El Filibusterismo which I am using to them.) (P3)

\section{Theme 5: Assistance Mismatch to the needs of the school}

The participant expresses his need for books and equipment and shares his sentiment on the workload that he has other duties and responsibilities aside from being a teacher. Shabiralyani (2015) concluded in his study that high school teachers lacked time and proper equipment which they could not afford from their school budget. The above perspective implies then that provision of assistance does not match to what are the actual needs of the teacher and students which will affect the outcome of the lessons. Lack of monitoring and immediate response may be the reason for this situation of this study.

Significant Statement 1. "Ako manla it property custodian, maaram ako it kulang hit libro, may mga reports ko na ginahahatag ko ha DepEd ngadto ha division, maaram hira kon ano man kulang pero, an usually an ira ginhahatag nira an diri gud mga needs, like yana an ira ginhatag an MAPEH 7 damo na ito nga libro nganhi an mga kulang lugod waray lugod katatagi like Filipino 7 ginreport ko na adto kulang hin libro waray man lugod naghatag yana. Damo manla it amon trabaho diri manla teacher

(I am the Property Custodian; I know what books are lacking. There are reports I send to DepEd Division, they know what lacks but what they usually give is not what the needs are like now they gave MAPEH 7, there are already many books on that here. The ones that lack are not given like Filipino 7. I already reported that there are lacking books. They did not give now. We have a lot of work not only as a teacher.) (P4)

\section{Conclusion and Recommendations}

This study was undertaken to stimulate a critical discussion in the needs assessment of grade 8 instructional materials in teaching Filipino. There are needs when it comes to grade 8 instructional materials in teaching Filipino. But because of the unavailability of these materials, the initiative of the teacher has been observed. The use of instructional materials in teaching Filipino facilitates and enhance the teaching-learning process. It was also believed that the use of audio-visual materials stimulates students' interests and they become more interactive and focused.

Results of this study serve as a reminder for the school heads that they should take the necessary action when it comes to the needs of the students and teachers inside the classroom. Emphasis must be placed on the use of instructional materials to enhance and improve the teaching-learning process. Teachers should have some training and workshops when it comes to teaching strategies, approaches and methods, and training when it comes to technological equipment for its effective use and dissemination of knowledge.

\section{References}

(n.d.). Retrieved from Instructional Materials Selection and Adoption: Textbook Selection and Adoption: http://www.tsbvi.edu/e-policy/1676-efaa-instructional-materials-selection-and-adoption-textbook-selection-andadoption

Ambrosio Jr., N. (2016). Instructional materials making the teaching and learning process easy, more meaningful and understandable. Pampanga: Press Reader. Retrieved from Instructional materials making the teaching and learning process easy, more meaningful and understandable.

Bugler, D. (2017). How Teachers Judge the Quality of Instructional Materials. 14.

Campbell, C. P. (1999). "Instructional materials: their preparation and evaluation", Journal of European Industrial Training. Emerald Insight, pp.57-107.

Cox, J. (n.d.). Teaching Strategies: Selecting Instructional Materials. Retrieved from http://www.teachhub.com/teachingstrategies-selecting-instructional-materials

Dick. (2010). Instructional Design Theory. $\quad$ Retrieved from https://sites.google.com/a/nau.edu/educationallearningtheories/home/instructional-design-theory

Fikre, \& Wondimtegegn, F. Y. (2020). Efficacy of Audio-Visual Teaching Materials in EFL Classes: Thereüseo Two Elementary Schools in Addis Ababa, Ethiopia. International Journal of Scientific and Research Publications, 8. 
Gravoso, R. a. (2008). Design and Use of Instructional Materials for Student-Centered Learning: A Case in Learning Ecological Concepts. The Asia-Pacific Education Researcher, 109-120.

Handbook for Instructional Materials. (n.d.). Pasco: District School Board of Pasco County Instructional Media \& Technology Services.

Lashley, L. (2019). A Reflective Analysis of the Selection and Production of Instructional Material for Curriculum Delivery at the Primary Level in Postcolonial Guyana.

Legaspi, A. (2014). Lack of materials, facilities still hound K to 12 implementation. Manila: GMA News Online.

Shabiralyani, G. e. (2015). Impact of Visual Aids in Enhancing the Learning Process Case Research: District Dera Ghazi Khan. Journal of Education and Practice, 9.

Teaching Materials. (2017). Retrieved from Office of the VP for Teaching and Learning: https://www.ucc.ie/en/teachlearn/resources/udl/materials/

Tety, J. L. (2016). Role of Instructional Materials in Academic Performance in Community Secondary Schools in Rombo District.

The Importance of Learning Materials in Teaching. (2016, June 15). Retrieved from Quick Tips for Teachingg: http://education.gov.gy/web/index.php/teachers/tips-for-teaching/item/2036-the-importance-of-learning-materialsin-teaching

Tuimur, H. N. (2015). Availability ad Use of Instructional Materials in the Teaching of Conflict and Conflict Resolution. International Journal of Education and Practice, 11. 